技術ノート

\title{
スーパーミラーを用いた熱中性子集光デバイスの開発
}

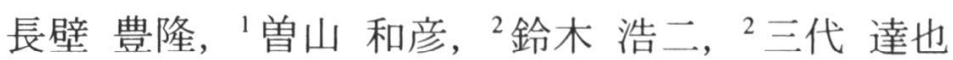
(日本原子力研究所先端基礎研究センター, '日本原子力研究所中性子利用研究センター,

$$
\text { 2アドバンスト・マシン・工房) }
$$

\section{Development of Thermal Neutron Focusing Device Using Supermirrors}

Toyotaka Osakabe, ${ }^{1}$ Kazuhiko Soyama, ${ }^{2}$ Koji Suzuki, ${ }^{2}$ Tatsuya Miyo JAERI-ASRC, 'JAERI-NSRC, ${ }^{2}$ Advanced Machine Workshop

\section{1.はじめに}

超高圧や強磁場などの極限環境下の中性子散乱 実験では，実験装置の制約から試料サイズが微小 なものになってしまうことは避けられない。高輝 度放射光に比べ析違いに弱い中性子ビーム強度で これを補うには, 中性子を試料位置に精度良く集 光して実効的な強度を稼ぐことや散乱中性子を効 率良く検出することが有効である.

中性子を集光する方法としては，(1)中性子ミ ラーによる反射光学デバイス, (2)物質界面での 屈折を利用した屈折光学デバイス, (3)勾配のあ る磁場中で中性子磁気モーメントが受ける力を利 用した磁気屈折光学デバイスが挙げられる。実 際に $\mathrm{MgF}_{2}$ 製の凹レンズを多数組み合わせた屈折 光学デバイスが実用化されており, NIST の SANS に設置されている[1]. また理研を中心とした NOP グループにより $\mathrm{MgF}_{2}$ 製のフレネルレンズを使用 した屈折光学デバイスや超伝導 6 極磁石を利用し た磁気屈折光学デバイスの開発が精力的に進めら れている[2]. しかしながらこれらの光学デバイ スは主に冷中性子用, 特に小角散乱装置において 低散乱角度側の測定範囲拡大と中性子強度利得を 目指したもので, 固体の(静的あるいは動的)構造 解析のためには 1 2 A程度の熱中性子を使用す ることが望ましい。我々は, 熱中性子集光が極 限環境下の固体研究にとって不可欠な技術的要素 であり，中性子スーパーミラーの反射を利用した 光学デバイスが最も効果的であろうと考えて, 集 光デバイスの開発を行ったので本稿で紹介寸る.

\section{2. 熱中性子集光デバイスの開発}

筆者の 1 人(TO)は以前, 高圧力下中性子散乱に おいて微小試料からの非常に弱い磁気散乱を観測 することを目的に, 円形状のスーパーミラーを試 料上流に多数枚配置する熱中性子集光デバイスの 有効性について検討, 報告した[3]. 今回開発し た集光デバイスはこの原理に基づいている. Figure 1 に集光デバイスの概念図を示す。この集 光デバイスは汎用の中性子散乱装置に設置さ れる. 幅 $50 \mathrm{~mm}$ 程度の第 2 コリメータから出て くる発散を持った中性子であっても複数の円形状 ミラーのいずれかの内側で等角度で反射を起こし，
30. $\mathrm{NiC} / \mathrm{Ti}$ neutron supermirror with the shape of a circle.

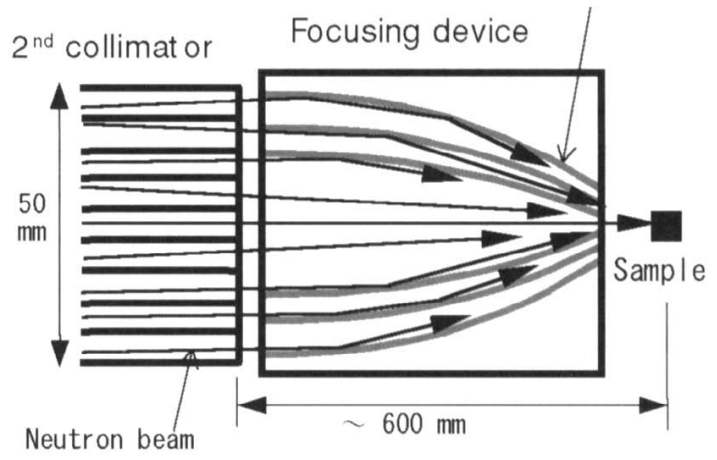

Figure 1. Schematic drawing of the neutron focusing device.

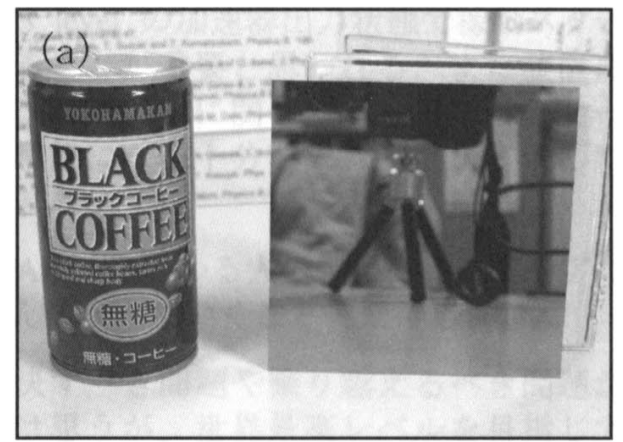

(b) LTAS, $\lambda=3.80 \AA$, Beam width: $0.5 \mathrm{~mm}$

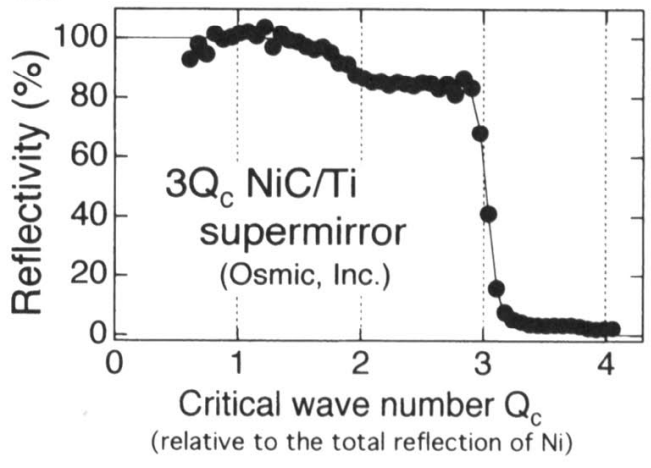

Figure 2. (a) Photograph of the neutron supermirror. (b) The reflectivity of the mirror. 
第 2 コリメータと試料間の $600 \mathrm{~mm}$ 程度の短い距 離で試料部分に集光するというものである。集光 原理が全く幾何学的なものなので, 集光効率は変 化するが，どの波長の中性子に対しても焦点が変 化することがない。 また，デバイス自体がコンパ クトなので気軽に持ち運んで中性子散乱装置に設 置できるという利点がある。

我々は中性子スーパーミラーとして Osmic 社 製で $100 \mathrm{~mm} \times 100 \mathrm{~mm}$ サイズ, $0.25 \mathrm{~mm}$ のシリコ ン基盤に蒸着された $\mathrm{NiC} / \mathrm{Ti}$ の $3 \mathrm{Q}_{\mathrm{C}}$ 仕様のものを 75 枚用意した。このミラーは基盤が薄いため, ある程度自由にミラーの形状を制御することがで きる. Figure 2 にスーパーミラーの写真と実測し た反射率のデータを示す。後で述べるシミュレー ション計算ではこのデータを使用している.

用意したスーパーミラーの枚数は限られている ので, Figure 1 の円形状ミラーの長さと円形状ミ ラーの設置枚数の間で最適な条件を探す必要があ る.また，デバイスの設置場所は試料上流になる が, 冷凍器の使用を考慮して試料から最低 $150 \mathrm{~mm}$ 以上上流に設置する必要がある. 我々は中性子散 乱実験デバイス用の汎用 2 次元モンテカルロシミ ュレーションソフトウェア(McStas もどき)を新た に構築し, 集光デバイスを JRR-3M の TAS-1(2G) 分光器に設置する場合についておよそ 200 通りの 計算を行い, 最適なデザインを決定した。最終的 なパラメータを Table 1 に示す. デバイスの長さ は $400 \mathrm{~mm}$ で円形状ミラーは片側 9 枚, 焦点距離 はデバイス下流端から $150 \mathrm{~mm}$ となっている。

Figure 3 にシミュレーションによる, 2.36 凡に単 色化した中性子に対する分布プロファイルをいく つか示す. 最大強度を得るために第 2 コリメータ をブランクガイドの状態とした計算なので, 半值 幅 90 分程度の発散角度を持つ中性子が集光デバ イスに入射していることになる，最適条件では集 光デバイスを設置しない場合に比べ, 試料幅 $3 \mathrm{~mm}$ の積分強度で約 3 倍の利得がある。

集光デバイスの実際の製作にあたっては, 円形 状ミラー間の特殊な形状のスペーサを製作し,こ のスペーサで各ミラーを挟み, 両外側の枠で締め

\begin{tabular}{|c|c|c|}
\hline \multicolumn{3}{|c|}{ デバイス長:400mm } \\
\hline \multicolumn{3}{|l|}{ 焦点距離: 550mm } \\
\hline \multicolumn{3}{|c|}{ 円形状ミラー:全 18 枚 } \\
\hline ミラー(外側から & 5) 中心 & 半径 \\
\hline 1 & $(0.0,-6037.50)$ & 6062.50 \\
\hline 2 & $(0.0,-6756.16)$ & 6778.51 \\
\hline 3 & $(0.0,-7667.81)$ & 7687.51 \\
\hline 4 & $(0.0,-8862.44)$ & 8879. 49 \\
\hline 5 & $(0.0,-10496.27)$ & 10510.67 \\
\hline 6 & $(0.0,-12866.47)$ & 12878.22 \\
\hline 7 & $(0.0,-16616.33)$ & 16625.43 \\
\hline 8 & $(0.0,-23446.39)$ & 23452.84 \\
\hline 9 & $(0.0,-39800.73)$ & 39804.53 \\
\hline \multicolumn{3}{|c|}{$\begin{array}{l}\text { 原点はデバイスの人りロ中心。残りのミラー } \\
\text { は上記と反転位置。 }\end{array}$} \\
\hline
\end{tabular}

Table 1. Optimum parameter set for the focusing device.
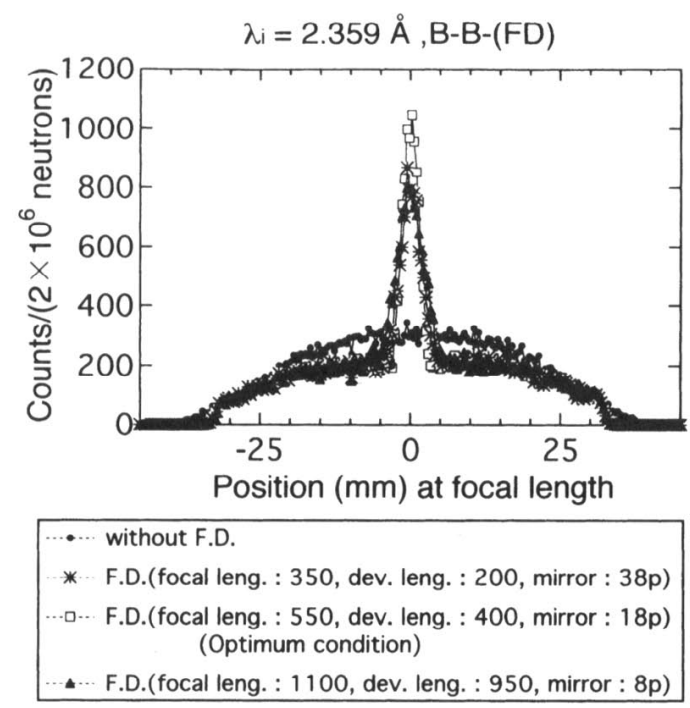

Figure 3. The results of the Monte Carlo simulation of the neutron intensity in some conditions.

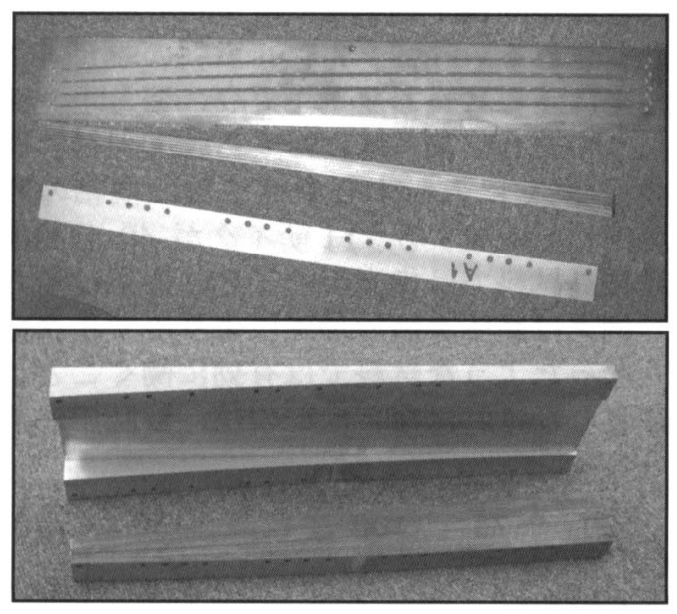

Figure 4. Photograph of the components of the focusing device.

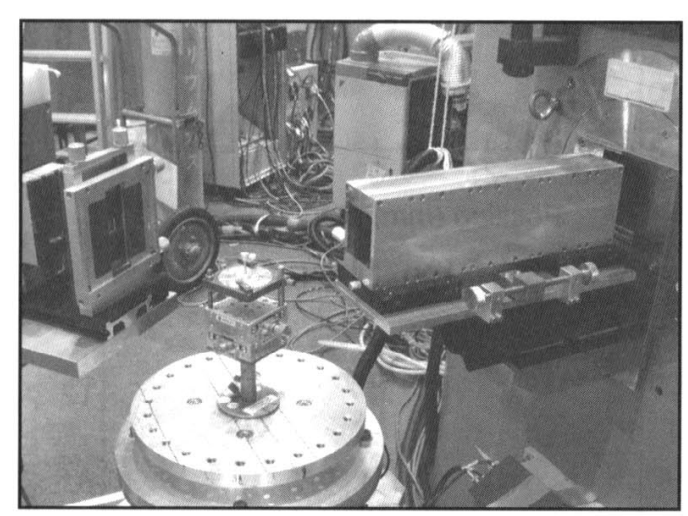

Figure 5. Photograph of the focusing device installed in the TAS-1(2G) spectrometer.

付けて円形状の精度を出す構造とした。初めはガ ラスエポキシ樹脂に対してエンドミル加工でスペ 一サを製作したが精度が出なかったため, 材質を 2017 番の $\mathrm{Al}$ 合金に変えて放電加工で製作した (Figure 4). 完成した集光デバイスを TAS-1 分光 
器に設置した様子を Figure 5 に示す. 集光デバイ スは, 中性子分光器の光学ベンチに取付けられた 微調整機構の上に設置される.これにより中性子 ビームに対して上下流方向と横方向に位置調整が 可能となっている.

Figure 6 に, 集光デバイスを TAS-1 に設置し, 焦点距離にイメージングプレートを置いて測定し た中性子分布プロファイル，及び，シミュレーシ ヨンによるプロファイルを示す. 特に Figure 6(b) は, Figure 1 で集光デバイス中心部の円形状ミラ 一がない場所の入り口に Cd マスクをした場合で あり，ミラーで反射した中性子のみの分布に相当 する. 両測定とも実測の結果はシミュレーション の結果とおおよそ一致していることから，実際に ミラーの反射により集光しており，デバイスとし てほぼ所定の性能が出ていることが判る.

集光デバイスによる集光では，原理上，発散角 の大きい中性子がより多く試料に入射することに なる. そのため, 集光デバイスの効果は単結晶の 干渉性散乱を測定する場合には試料のモザイク分 布に影響される. Figure 7 に, 試料のモザイク分 布と集光によるビーム発散をガウス型とする場合 に，1 つの結晶回転角度に対する強度利得の様子 を示す. (試料に入射する中性子数は横軸の発散 角に比例して増加する.)モザイクが 40 分程度の 良い単結晶試料では集光デバイスの効果は殆どな いが，例えば高圧実験で加圧によりモザイク分布 が広くなったような試料では有効に働くことが判 る. 注意しなければならないのは，散乱中性子も
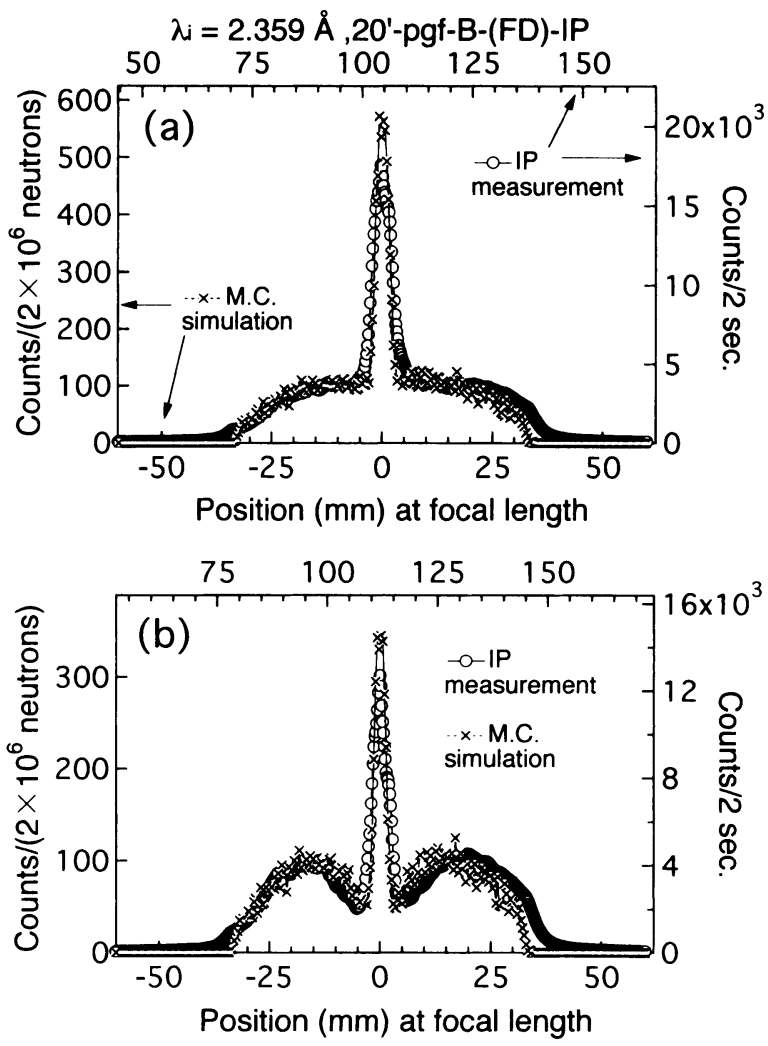

Figure 6. The comparison of the neutron intensity by the M.C. simulation with that by the IP measurement.

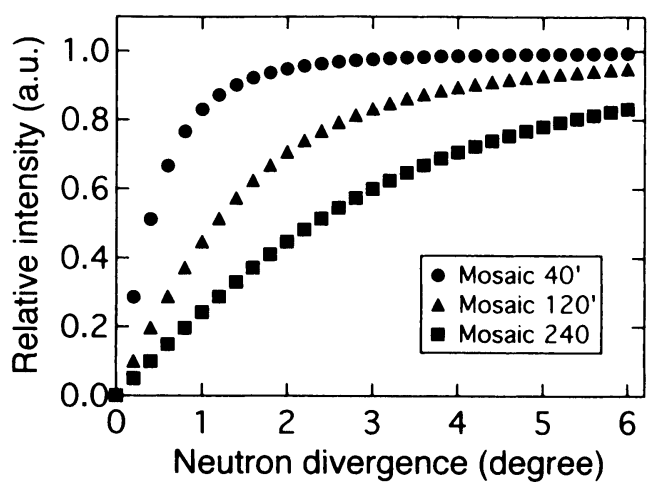

Figure 7. The relation between the intensity at the Bragg angle and the divergence of the incident neutron beam.

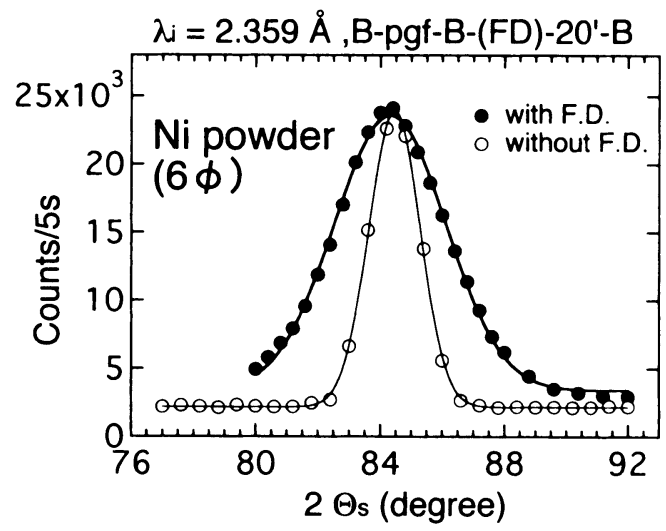

Figure 8. Diffraction peaks of Ni measured with or without the focusing device.

広い発散角を持つということである。ブラッグ反 射などの干涉性散乱を測定する場合，入射中性子 ビームの広がりはそのまま広がった散乱中性子と なる．集光デバイスを効率良く利用するには例え ば LLB で行われている様に検出器側を 2 次元に するなど, 試料下流側の対策も必要となる[4]. また，典型的な中性子散乱装置で使用する場合に は分解能の緩い縦方向に使用するのも良いかもし れない.

Figure 8 に, 実際に直径 $6 \mathrm{~mm}$ の容器に入った $\mathrm{Ni}$ 粉末試料を焦点位置に置いて測定した回折パ ターンを示す. 測定前に集光デバイスの完全な位 置調整をしておらず，また，試料の直径が大きく て集光の効果が見えにくいが，それでもピーク積 分強度で 2 倍強の利得がある.この測定では 1 次 一元検出器を移動してスキャンを行っているが，上 で述べたように 2 次検出器を使用するなどの】夫 で測定効率を上げることが重要になる。

\section{3.おわりに}

本稿では， $3 \mathrm{Q}_{\mathrm{C}}$ 仕様のスーパーミラーを円形 状に多数枚配㯰することによって熱中性子でも $600 \mathrm{~mm}$ 程度の比較的短い距離で集光できること を示した。 今後より高い $\mathrm{Q}_{\mathrm{C}}$ 仕様のスーパーミラ 一が気軽に利用できるようになれば，同じ設計で 
より効率のよいデバイスの開発が可能になる. (例 えば， $4 \mathrm{Q}_{\mathrm{C}}$ 仕様のミラーを使用すれば， $2.36 \AA$ の中性子に対して試料幅 $3 \mathrm{~mm}$ の積分強度で 4 倍 の利得が見込まれる。）また，今回開発した集光 デバイスは 2 次元面内の集光であるが，理研で開 発が行われているような自由曲面スーパーミラー の利用が将来可能になれば，微小試料に対する実 験効率を飛躍的に上げることができると考えられ る[5].

\section{謝辞}

この開発は原研先端基礎研究センター極限環境 中性子散乱法研究グループのテーマの 1 つとして 行われたものです. 同グループの石井氏にはシミ ュレーションソフトウェアの作製で, 原研中性子 利用研究センターの田中氏には IP 測定で御協力 頂きました。両氏に感謝致します。

参考文献

[1]S.-M. Choi et al., J. Appl. Cryst., 33, 793 (2000). [2]例えば, 奥隆之 他, 日本中性子科学会第 3 回 年回 P1-068, 篠原武尚 他, 同 P1-069, 鈴木淳市
他, 同 P1-070, 安達智宏 他, 同 P2-069, H. M. Shimizu et al., Physica B 311, 123 (2002) など.

[3]長壁豊隆, 波紋 10, 25 (2000).

[4]I. N. Goncharenko et al., Neuron News 14, 20 (2003).

[5]池田一昭 他, 日本中性子科学会第 3 回年会 P2-067, 曽山和彦 他, 日本物理学会 2002 年秋季 大会 $8 \mathrm{aSL}-5$

\section{Abstract:}

The neutron-focusing is an indispensable technical element in the experments under extreme condition with tiny samples. In this article, the development of the thermal neutron focusing device is reported. The device has 18 pieces of the $3 \mathrm{QC} \mathrm{NiC/Ti}$ neutron supermirrors with the shape of a circle. The extension of the end of each mirror meets at a focal point (sample position). Neutrons are repeatedly reflected with the same angle by the inner side of the circle and arrive at the sample position. The test results show that the integrated intensity increases by a factor of 2 or more for the neutron wavelength of $2.36 \AA$. 